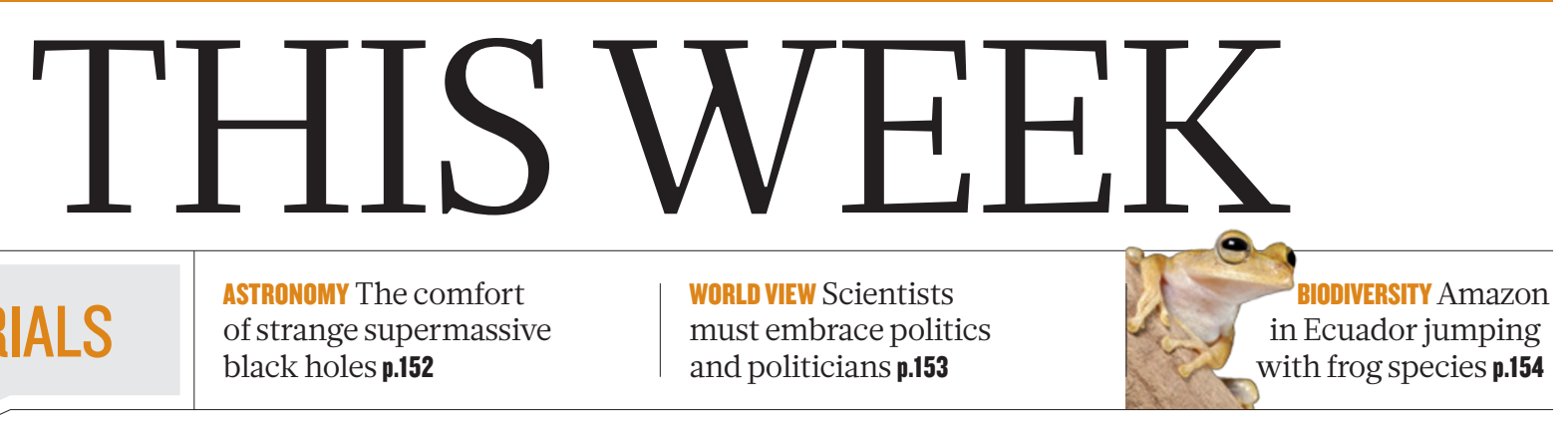

EDITORIALS black holes p.152 must embrace politics

and politicians $\mathbf{p . 1 5 3}$ in Ecuador jumping with frog species $\mathbf{p . 1 5 4}$

\title{
The press under pressure
}

\author{
With the Leveson inquiry scrutinizing journalistic practice in the United Kingdom, scientists \\ should take the opportunity to fight back against agenda-driven reporting.
}

$\mathrm{E}$ veryone has an example of the scientific ignorance of the press, but researchers in Britain probably have more than most. With stories ranging from ludicrous (wind turbine attacked by aliens) to downright irresponsible (promoting the link between childhood vaccinations and autism), the fourth estate in the United Kingdom has hardly covered itself in glory when it comes to science and scientific issues.

Other countries have similar grievances, of course - particularly the United States, where right-wing talk radio and cable television regularly air anti-science views on everything from global warming to creationism. Stem-cell scientists in Germany and transgenic-crop researchers in France have also been assailed by journalism out of step with the scientific evidence that it claims to examine. But there is a sense that the situation is more acute in tabloid-driven Britain, particularly given the distasteful news-gathering techniques that are now under the microscope like never before.

In Britain, eyes are on an inquiry into the standards and ethics of the press, headed by Lord Justice Brian Leveson. Widely known as the 'phone-hacking inquiry', triggered as it was by revelations about the extent of illegal eavesdropping at the now-defunct News of the World newspaper, the judicial investigation in fact has a much wider scope. In his opening remarks, Robert Jay QC, counsel to the inquiry, said that he expected members of the scientific community to submit evidence that sections of the press were causing real harm by not basing their commentaries on evidence and not applying the scientific method to their reports. But his remarks seem to have surprised many within the community he was referring to - a subsequent search by the Science Media Centre, an advocacy group in London, found just a single planned submission, and it now intends to send its own.

This is a wasted opportunity. Too often, talk about the difficult relationship between the media and science gets bogged down in wellmeaning but ultimately naive discussion of how to 'help' reporters to get their facts straight. Should journalists send stories to scientists to be vetted before publication? Should they have scientific training? Should scientists be trained to offer sound bites?

Alastair Campbell, the former communications chief for the UK government and a man who knows a thing or two about sound bites, better characterized the problem when he told the Leveson inquiry about "agenda-driven journalism regardless of facts". Campbell was referring to the media fixation with autism and childhood vaccinations, but it could have been anything from climate change (on which positions range from 'it's not dangerous' to 'it's going to kill us all') or volcanic ash and aviation (it's not dangerous) to bird flu (it's going to kill us all).

Sometimes the agenda is obvious and explicitly political. More often, it is the instinctive overreach of a story-teller who chooses what to include to make their tale as interesting as possible. Either way, the problem runs deeper than reporters regularly confusing bacteria and viruses, however irritating that may be to some. Witness the list of the top 100 UK political journalists of 2011, as decided by Total Politics

magazine last week. In at number 14 is Christopher Booker, a columnist for The Sunday Telegraph. Not satisfied with Booker being "skeptical about global warming", the magazine partly credits his high rank to his claims that evidence to prove that passive smoking and exposure to asbestos cause cancer "does not exist".

Journalism that favours attitude over accuracy is more common than scientists suspect, and not just on the comment pages or in the tabloids. And it is also more damaging - with news editors

\begin{abstract}
"Journalism that favours attitude on high-profile stories, no matter what the science says.
\end{abstract} over accuracy is more common than scientists suspect." behind the scenes ordering certain lines

The evidence offered to Lord Leveson shows that science is far from alone in this treatment: parents of missing and murdered children have queued up to tell harrowing stories of blatant misrepresentation, on top of the indignity of having voicemails hacked.

But science has a way to respond that others do not. Through online forums, blogs and Twitter, a cottage industry has grown up around instant criticism of dodgy scientific claims and dubious findings. This parallel journalism is increasingly coming to the attention of the mainstream press - as demonstrated by the rising number of stories in the press that were first broken by blogs.

It may seem thankless at times, but the army of online commentators who point out the errors, the inconsistencies and the confounding factors, and from time to time just scream 'bullshit', have the power to hold the press to account. This ongoing war of attrition against those who would put their own agendas above the facts cannot take away their platform, but it can chip away at something they prize even more: their relevance, and with it their pernicious influence. -

\section{Troubled waters}

\section{Protected areas are only the start of the road to reforming our relationship with the seas.}

$\mathrm{T}$ The easiest way to create a nature reserve from a car park is simply to declare it as such. The land is then designated as protected, and counts towards the relevant government's targets to set aside a certain amount of its territory from development. That is a ridiculous example, of course, and would never happen on land - so why do we allow a similar exercise to happen in the sea?

No one should doubt that our seas need protection. Overfishing, pollution and climate change are fundamentally changing some of the 